\title{
Evaluation of Antibacterial Activity of Aqueous, Ethanolic and Methanolic Extracts of Areca Nut Fruit on Selected Bacteria
}

\author{
Neda Jam $\left(\mathbb{D},^{1}\right.$ Reza Hajimohammadi $\mathbb{D}^{1},{ }^{1}$ Parvin Gharbani $\mathbb{D}^{2},{ }^{2}$ and Ali Mehrizad ${ }^{3}{ }^{3}$ \\ ${ }^{1}$ Department of Chemical Engineering, Ahar Branch, Islamic Azad University, Ahar, Iran \\ ${ }^{2}$ Department of Chemistry, Ahar Branch, Islamic Azad University, Ahar, Iran \\ ${ }^{3}$ Department of Chemistry, Tabriz Branch, Islamic Azad University, Tabriz, Iran
}

Correspondence should be addressed to Parvin Gharbani; parvingharbani@yahoo.com

Received 24 November 2020; Revised 30 March 2021; Accepted 9 April 2021; Published 16 April 2021

Academic Editor: Abadi Kahsu Gebre

Copyright (c) 2021 Neda Jam et al. This is an open access article distributed under the Creative Commons Attribution License, which permits unrestricted use, distribution, and reproduction in any medium, provided the original work is properly cited.

Today, the tendency to use of natural preservatives to increase food security has expanded. In the present study, antibacterial effects of Areca Nut fruit extracts were evaluated against Staphylococcus aureus, Escherichia coli, Salmonella enterica, and Enterobacter aerogenes bacteria using agar disc diffusion technique. Methanol, ethanol, and water were used as solvents for extraction by maceration method, and extracts were analyzed by GC-MS. The antibacterial activity was evaluated using microtiter broth dilution method to determine minimum inhibitory concentration (MIC) and minimum bactericidal concentration (MBC). Results revealed that all ATCC strains were significantly inhibited by ethanolic and methanolic extracts. Escherichia coli produced a significantly larger zone of inhibition for Gentamicin $(35 \pm 0.65 \mathrm{~mm})$ and Penicillin $(25 \mathrm{~mm} \pm 0.56)$, while Enterobacter aerogenes produced smaller zone of inhibition for Gentamicin $(20 \pm 0.87 \mathrm{~mm})$ and Penicillin $(15 \pm 0.87 \mathrm{~mm})$. Also, methanolic extract had considerable antibacterial activity with MIC value of $1.56 \mathrm{mg} / \mathrm{mL}$ against Escherichia coli. All of extracts were used to evaluate antibacterial effects in prepared cake, and as a result, all pathogenies were the most sensitive by methanolic extract in $100 \mathrm{mg} / \mathrm{L}$ of concentration except Escherichia coli that were more sensitive by ethanolic extract. In conclusion, the Areca Nut fruit extracts may be used as a natural preservative in food industries. Future studies should focus on the effect of Areca Nut fruit extracts in bakery and drinking industries.

\section{Introduction}

Currently, employing plant sources as an alternative to chemical additives in medicines and foods is growing $[1,2]$. Antimicrobial, antioxidant, and anticancer impacts of herbal extracts and essences have drawn a considerable attention in food and pharmaceutical industries for years [3]. Herbal extracts and their components have been known to possess antimicrobial properties [4], which among them we can mention a plant known as Areca Nut $[5,6]$. The Areca Nut is the fruit of the areca palm which grows in much of the tropical Pacific, Southeast and South Asia, and parts of east Africa. It is commonly referred to as betel nut, too $[7,8]$. Nutrient content of Areca Nut is carbohydrate, lipid, fibre, polyphenol and alkaloid 0.3 to $0.6 \%$, tannin of $15 \%$, and fat of $14 \%$ [9]. All parts of the Areca Nut such as husks, shoots, buds, leaves, and roots are used in medicinal [9]. Chemical compounds including Isoguvocine, Choline, Alkaloids, Arecoline, Acecainide, Arecoline, and Guanine have been found in Areca Nut extract [10]. Fruits of this plant include Catechin alpha and seeds contain Arecodin, Arecatine, BetaSitosterol, about $15 \%$ tannin, approximately $14 \%$ fatty acids, little sucrose, Mannan, and Galactan [11, 12]. Catechins are produced by plant naturally and are a metabolic secondary from tannin [13] and have antioxidant and antimicrobial properties. Tannin in Areca Nut exhibits antibacterial and antifungal activities, too $[10,14,15]$. Seeds contain at least four alkaloids, including Arecaidine, Arecoline, Guvacine, and Guvacoline, which among them Arecoline and Guvacoline are the most important components. Both ingredients enhance natural elasticity and peristaltic wave observed in the intestines, without any damage to circulatory and respiratory systems [16]. Antibacterial effect of Areca Nut leaves extract against B. cereus and P. fluorescens was reported 
[17]. Also, its seed could inhibit the growth and propagation of S. mutans [9]. Areca Nut is known as a powerful antibacterial and antioxidant due to its content of tannin (15\%) [9, $18,19]$.

Since Areca Nut fruit has been used for centuries with no significant side effects [10], this study was aimed to evaluate of antibacterial effect of methanolic, ethanolic, and aqueous extracts of Areca Nut against Staphylococcus aureus, Escherichia coli, Salmonella enterica, and Enterobacter aerogenes pathogens. Since mentioned pathogens are the main pathogens found in bakery products $[20,21]$, extracts efficiency was investigated as natural antimicrobial food preservatives in cake instead of artificial ones.

\section{Materials and Method}

2.1. Materials. Areca Nut's fruit was obtained from the Research and Development unit of Mers herbal pharmaceuticals, Tabriz, Iran, and was stored in a dark place at $4^{\circ} \mathrm{C}$.

2.2. Chemicals and Growth Medium. Brain heart infusion (BHI) broth medium, blood agar medium, plate count agar medium, medium nutrient broth, Mueller Hinton broth medium, normal saline, glycerin, phosphate-buffered saline (PBS), sheep blood defibrinated, 0.5 MC Farland tube, ethanol, and methanol. All of the chemicals were purchased from Merck Company. Gentamicin and Penicillin were purchased from Sigma Aldrich company.

2.3. Bacterial Strains. The used strains were (ATCC 6538) Staphylococcus aureus, Escherichia coli (ATCC 25922), Enterobacter aerogenes (ATCC 13048), and Salmonella enterica (ATCC 9270). All were prepared from the Pasteur Institute of Iran and were stored at $4^{\circ} \mathrm{C}$.

2.4. Preparation of Extracts. After washing, the collected plants were dried in a freeze dryer for $24 \mathrm{hr}$ and, then, ground to fine powder by an electric blender and sieved (mesh 25). The powdered plants were dried again in an oven at $40^{\circ} \mathrm{C}$ for $24 \mathrm{hr}$ and then used to preparation of extract. Extracts were prepared by dissolving $2 \mathrm{~g}$ of the powder in $50 \mathrm{~mL}$ of methanol $(80 \%)$, ethanol $(80 \%)$, and distilled water to obtained methanolic, ethanolic, and aqueous extracts of Areca Nut, respectively. It was mixed vigorously for 2 min and concentrated at $23^{\circ} \mathrm{C}$ for $24 \mathrm{~h}$ in a laboratory water bath. The mixtures were then filtered through a $0.45 \mu \mathrm{m}$ filter, concentrated by a rotary evaporator, and dried at $40^{\circ} \mathrm{C}$. The extracts were stored at $4^{\circ} \mathrm{C}$ in dark glass bottles.

2.5. Preparation of Bacterial Culture. At first step, BHI Broth was prepared according to the manufacturer's protocol. Then, $0.5 \mathrm{~mL}$ of lyophilized cultures was added to $4 \mathrm{cc} \mathrm{BHI}$ broth medium and incubated for $18-16 \mathrm{~h}$ at $37^{\circ} \mathrm{C}$ and was repeated for two times. From the first culture, 1-2 drops were inoculated on blood agar medium and potato dextrose agar (PCA) medium and were spread over the surface of the solid medium. Petri dishes were incubated at $37^{\circ} \mathrm{C}$ for $24-48 \mathrm{~h}$. The second culture was used to prepare stock. Accordingly, nutrient broth medium and sterile $18 \%$ glycerol were mixed at a ratio of $1: 5$, transferred in $500 \mu \mathrm{l}$ volumes to Eppendorf microtubes, and stored at $-20^{\circ} \mathrm{C}$. After a few days, prepared cultures were transferred to BHI broth medium and after 16-18 h were revived for analysis. To check the purity of the cultures, the bacteria were cultivated in blood agar medium. In order to perform a disk diffusion (DD) experiment, bacterial suspensions by turbidity of the $0.5 \mathrm{McF}$ arland were prepared, and the inoculum was provided directly from the distinct colonies.

2.6. Dilution. Dry extracts were diluted with sodium phosphate buffer solution $(\mathrm{pH}=7.2,100 \mathrm{mg} / \mathrm{mL})$ and were shaken vigorously for $2 \mathrm{~min}$ by a vortex mixer. Homogenized mixtures were filtered through a $0.22-\mu \mathrm{m}$-pore-size membrane filter.

2.7. Agar Disk Diffusion Assay. Agar well diffusion method is widely used to evaluate the antimicrobial activity of plants or microbial extracts [22]. The antibacterial activity of extracts was evaluated using the disk diffusion method. $20 \mathrm{~mL}$ of suspension containing bacteria was spread on Mueller Hinton agar. After drying agar culture plates, paper discs containing $100 \mathrm{mg} / \mathrm{mL}$ of extracts were evenly distributed over the surface of the plates. Then, the wells were punched over the plates of $6.4 \mathrm{~mm}$ diameter, and each extract was poured into separate wells. Plates soaked with Gentamicin and Penicillin $(0.006 \mathrm{mg} / \mathrm{mL})$ were used as positive control, and a plate soaked with pure solvent of aqueous solution was used as a negative control. Then, plates were incubated at $37 \pm 2^{\circ} \mathrm{C}$ for $24 \mathrm{~h}$. After incubation, the diameter of growth inhibition zone was measured in $\mathrm{mm}$ and recorded. Experiments were repeated three times.

2.8. Minimal Inhibitory Concentration (MIC) and Minimal Bactericidal Concentration (MBC). Minimal inhibitory concentration (MIC) and Minimal bactericidal concentration (MBC) were measured using the macrobroth dilution method [23]. Firstly, the cultures were incubated overnight and were diluted. A series of 10 test tubes were used to determine MIC (for each extract and for each studied bacterial species). 8 tubes containing Mueller Hinton Broth were employed for each one. Then, $1 \mathrm{~mL}$ of microbial suspensions and different dilutions $(1,10,100 \mathrm{mg} / \mathrm{mL})$ of the extract were added to each tube. Two tubes consisting of $9 \mathrm{~mL}$ of culture medium with $1 \mathrm{~mL}$ of diluted extract as a positive control and $9 \mathrm{~mL}$ of culture medium with $1 \mathrm{~mL}$ of bacterial suspension as a negative control were prepared. All tubes were incubated at $37^{\circ} \mathrm{C}$ for $24 \mathrm{~h}$. After incubation time, tubes were examined for turbidity caused by the inoculated bacteria. Experiments were repeated three times for each extract and each species. A sampling of all the tubes with no bacterial growth was performed, and the samples were cultivated using the pour plate procedure to determine MBC. So, a $1 \mathrm{~mL}$ suspension of each tube was mixed with $20 \mathrm{~mL}$ of Muller Hinton agar at $48^{\circ} \mathrm{C}$ in petri dishes. After a while, when agar solidified, plates were incubated for $24 \mathrm{~h}$ and tested for microbial growth. The lowest concentration of the extract at which no bacterial growth that was detected was regarded as $\mathrm{MBC}$. 


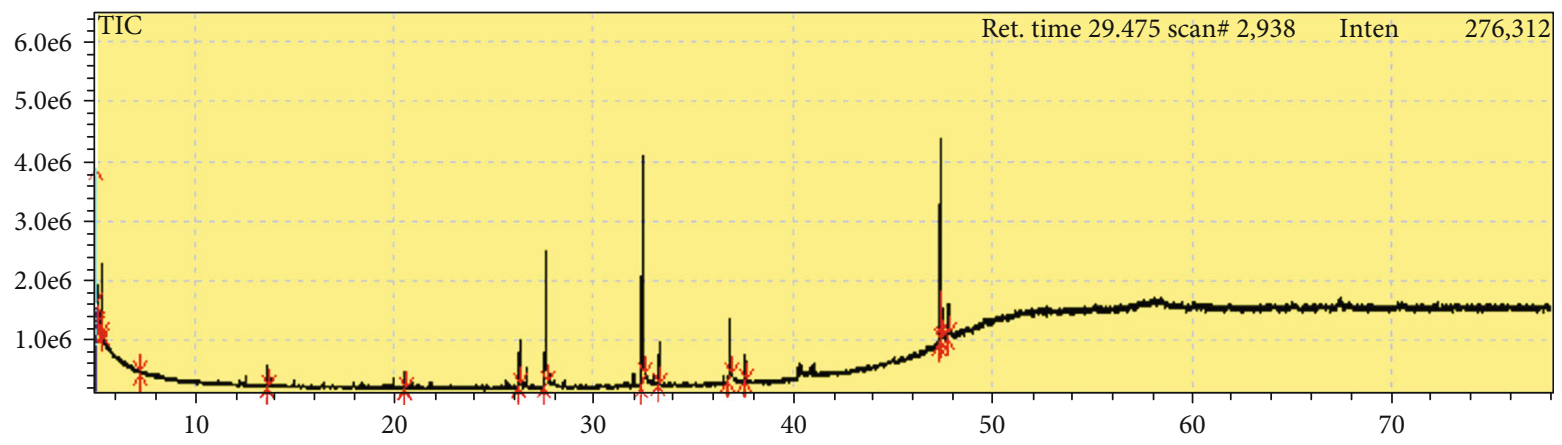

Figure 1: GC/MS chromatogram of Areca Nut extracts.

TABLE 1: GC-MS analysis of Areca Nut extracts.

\begin{tabular}{ccccc}
\hline No. & RT & Name of component & $\begin{array}{c}\text { Molecular } \\
\text { formula }\end{array}$ & $\mathrm{Mw}$ \\
\hline 1 & 5.039 & Cyclohexane & C6H12 & 84 \\
2 & 5.362 & Heptane & C7H16 & 100 \\
3 & 26.30 & 2,4-bis(1,1-dimethylethyl)- & C14H22O & 206 \\
4 & 27.61 & Phenol & C12H24O2 & 200 \\
5 & 32.46 & Tetradecanoic acid & C14H28O2 & 228 \\
6 & 47.44 & Diethylhexylphthalate & C24H38O 4 & 390 \\
\hline
\end{tabular}

2.9. Preparation of Cake. Eggs and sugar were mixed together; oil was added and mixed. Milk and Areca Nut fruit extract were mixed together and were added to the mixture and mixed well. Half the flour was added and mixed for 1 minute. In the end, baking powder and the rest of the flour were added and mixed for $1 \mathrm{~min}$. It was poured into a mold and baked for $20 \mathrm{~min}$ at $180^{\circ} \mathrm{C}$. Cakes were packed in heatsealed polyethylene packages and were kept at room temperature until later analysis.

2.10. Microbiological Analysis of Cakes. Depending on the components, each food may include a wide variety of microorganisms. Among them, some are the most important species in cake and confectionery industry, so microbiological testing is necessary to detect and identify them. The antibacterial activity of the solvent extracts of Areca Nut fruit was evaluated against some pathogens responsible for foodborne illness consisting of Staphylococcus aureus, Escherichia coli, Salmonella enterica, and Enterobacter aerogenes pathogens in cake. Cakes containing solvent extracts (three various concentrations) were prepared and assessed in $1^{\text {st }}, 30^{\text {th }}, 60^{\text {th }}$, and $80^{\text {th }}$ days. A cake without no extract was employed as control. A sterile cutter was applied for sampling from the surfaces, borders, underneath, and inside the sample. The specimens were put in a porcelain mortar (sterilized by heating) and were blended well, milled, and homogenized. 1 gram of specimen was placed into a sterile tube consisting of $9 \mathrm{cc}$ of physiological serum $(0.1 \mathrm{~g} / \mathrm{cc})$. Different concentrations of the sample $(0.01,0.001 \mathrm{~g} / \mathrm{cc})$ were prepared. $0.1 \mathrm{cc}$ of each dilution was removed by pipette and distributed uniformly on the surface of potato dextrose agar (PCA) medium by using standard hockey stick spreaders. Plates were stacked, fixed, and incubated at $37^{\circ} \mathrm{C}$ for $48 \mathrm{~h}$. The colonies were counted to determine the number of $\mathrm{CFU}$, and the results were recorded.

2.11. GC-MS Analysis. GC-MS analysis of the extract of Areca Nut fruit was performed using a Shimadzu GC-17A system comprising a Gas Chromatograph interfaced to a Mass Spectrometer (GC-MS) equipped with an Agilent J\&W (100\% Dimethylpolysiloxane) fused a capillary column ( $30 \mathrm{~m}, 0.32 \mathrm{~mm}, 1.00 \mu \mathrm{m})$ and FID detector. Helium gas was used as a carrier gas at a constant flow rate of $5 \mathrm{~mL} / \mathrm{min}$. The oven temperature was programmed from $70^{\circ} \mathrm{C}$ (for $2 \mathrm{~min}$ ), with an increase to $300^{\circ} \mathrm{C}(30 \mathrm{~min})$. Mass spectra were taken at $70 \mathrm{eV}$. The solvent delay was $3 \mathrm{~min}$, and the total GC/MS running time was $78 \mathrm{~min}$.

\section{Results and Discussion}

3.1. GC-MASS Analysis of Areca Nut Fruit Extracts. GCMASS analysis of Areca Nut fruit extracts is shown in Figure 1 and Table 1. Results showed six peaks which indicate the presence of 6 phytochemical constituents that is identified. As Table 1, Cyclohexane, Heptane, 2,4-bis(1,1-dimethylethyl)-Phenol, Lauric acid, Tetradecanoic acid, and Diethylhexylphthalate are the main constituents of Areca Nut fruit extracts.

3.2. Antibacterial Activity of Areca Nut Extracts. The test of antibacterial activity is carried out by measuring the clear zone developed in petri dish. The results showed that all extracts were effective in inhibiting the growth of bacteria except aqueous extract against Enterobacter aerogenes and Staphylococcus aureus bacteria (Table 2). The diameter of the bacterial growth inhibition zone in control samples (Penicillin and Gentamicin) was larger than the inhibition zone of the extracts. Escherichia coli produced a significantly larger zone of inhibition for Gentamicin $(35 \pm 0.65 \mathrm{~mm})$ and Penicillin $(25 \mathrm{~mm} \pm 0.56)$ than others, while Enterobacter aerogenes produced a smaller zone of inhibition for Gentamicin $(20 \pm 0.87 \mathrm{~mm})$ and Penicillin $(15 \pm 0.87 \mathrm{~mm})$. Produced inhibition zone by Staphylococcus aureus and Salmonella enterica for Gentamicin were $25 \pm 0.54$ and $30 \pm 1.01 \mathrm{~mm}$ and for Penicillin were $20 \pm$ 0.96 and $18 \pm 0.98 \mathrm{~mm}$, respectively. Enterobacter aerogenes were significantly inhibited by methanolic 
TABle 2: Inhibitory activity of Areca Nut fruit extracts on Staphylococcus aureus, Escherichia coli, and Salmonella enterica and Enterobacter aerogenes in various solvents by disc diffusion method.

\begin{tabular}{lccccc}
\hline \multirow{2}{*}{ Solvent } & \multirow{2}{*}{ Concentration $(\mathrm{mg} / \mathrm{mL})$} & \multicolumn{4}{c}{ Inhibitory activity of Areca Nut fruit extracts $(\mathrm{mm})$} \\
& & Enterobacter aerogenes & Salmonella enterica & Escherichia coli & Staphylococcus aureus \\
\hline $\mathrm{H}_{2} \mathrm{O}$ & 100 & - & $15 \pm 0.34$ & $15 \pm 0.45$ & - \\
$\mathrm{C}_{2} \mathrm{H}_{5} \mathrm{OH}$ & 100 & $10 \pm 0.23$ & $15 \pm 0.23$ & $17 \pm 1+01$ & $16 \pm 0.34$ \\
$\mathrm{CH}_{3} \mathrm{OH}$ & 100 & $12 \pm 0.65$ & $16 \pm 1.34$ & $19 \pm 087$ & $17 \pm 0.4$ \\
Gentamicin & 0.006 & $20 \pm 0.87$ & $30 \pm 1.01$ & $35 \pm 0.65$ & $25 \pm 0.54$ \\
Penicillin & 0.006 & $15 \pm 0.87$ & $18 \pm 0.98$ & $25 \pm 0.56$ & $20 \pm 0.96$ \\
\hline
\end{tabular}

TABLE 3: Result of significance test $(p<0.05)$ for the mean of the zone of inhibition at two solvents.

\begin{tabular}{|c|c|c|c|c|c|c|}
\hline \multirow[b]{2}{*}{ Bacteria } & \multicolumn{4}{|c|}{ Statistical analysis } & \multirow[b]{2}{*}{$\begin{array}{l}\text { Methanol } \\
\text { p-value }\end{array}$} & \multirow[b]{2}{*}{ Significant } \\
\hline & t-value & $\begin{array}{l}\text { Ethanol } \\
p \text { value }\end{array}$ & Significant & $\mathrm{t}$-value & & \\
\hline Enterobacter aerogenes & 4.35 & 0.007 & Yes & 3.87 & 0.002 & Yes \\
\hline Salmonella enterica & 3.23 & 0.0065 & Yes & 4.54 & 0.034 & Yes \\
\hline Escherichia coli & 4.32 & 0.004 & Yes & 3.99 & 0.002 & Yes \\
\hline Staphylococcus aureus & 2.54 & 0.001 & Yes & 3.1 & 0.004 & Yes \\
\hline
\end{tabular}

TABle 4: Antibacterial activity inhibition zone diameter (IZD), mm of Areca Nut fruit extracts on Staphylococcus aureus, Escherichia coli, Salmonella enterica, and Enterobacter aerogenes in various solvents by disc diffusion method.

\begin{tabular}{|c|c|c|c|c|c|c|c|c|c|c|c|}
\hline \multicolumn{3}{|c|}{ Escherichia coli } & \multicolumn{3}{|c|}{ Staphylococcus aureus } & \multicolumn{3}{|c|}{ Salmonella enterica } & \multicolumn{3}{|c|}{ Enterobacter aerogenes } \\
\hline \multirow{4}{*}{$\begin{array}{l}\mathrm{H} 2 \mathrm{O} \\
\mathrm{a}\end{array}$} & $\begin{array}{l}\text { Conc. } \\
\mathrm{mg} / \mathrm{mL}\end{array}$ & $\begin{array}{l}\text { IZD } \\
\mathrm{mm}\end{array}$ & \multirow{4}{*}{$\begin{array}{c}\mathrm{H} 2 \mathrm{O} \\
\mathrm{d}\end{array}$} & $\begin{array}{l}\text { Conc. } \\
\mathrm{mg} / \mathrm{mL}\end{array}$ & $\begin{array}{l}\text { IZD } \\
\mathrm{mm}\end{array}$ & \multirow{4}{*}{$\begin{array}{c}\mathrm{H} 2 \mathrm{O} \\
\mathrm{g}\end{array}$} & $\begin{array}{c}\text { Conc. } \\
\mathrm{mg} / \mathrm{mL}\end{array}$ & $\begin{array}{l}\text { IZD } \\
\mathrm{mm}\end{array}$ & \multirow{4}{*}{$\begin{array}{c}\mathrm{H} 2 \mathrm{O} \\
\mathrm{j}\end{array}$} & $\begin{array}{l}\text { Conc. } \\
\mathrm{mg} / \mathrm{mL}\end{array}$ & $\begin{array}{l}\text { IZD } \\
\mathrm{mm}\end{array}$ \\
\hline & 100 & $15 \pm 0.23$ & & 100 & $10 \pm 0.45$ & & 100 & $15 \pm 0.65$ & & 100 & $12 \pm 0.65$ \\
\hline & 10 & $7 \pm 0.34$ & & 10 & - & & 10 & $11 \pm 0.63$ & & 10 & $10 \pm 0.24$ \\
\hline & 1 & - & & 1 & - & & 1 & $8 \pm 0.34$ & & 1 & $10 \pm 0.12$ \\
\hline \multirow{4}{*}{$\begin{array}{l}\mathrm{EtOH} \\
\mathrm{b}\end{array}$} & $\begin{array}{l}\text { Conc. } \\
\mathrm{mg} / \mathrm{mL}\end{array}$ & $\begin{array}{l}\text { IZD } \\
\mathrm{mm}\end{array}$ & \multirow{4}{*}{$\begin{array}{c}\mathrm{EtOH} \\
\mathrm{e}\end{array}$} & $\begin{array}{l}\text { Conc. } \\
\mathrm{mg} / \mathrm{mL}\end{array}$ & $\begin{array}{l}\text { IZD } \\
\mathrm{mm}\end{array}$ & \multirow{4}{*}{$\begin{array}{c}\mathrm{EtOH} \\
\mathrm{h}\end{array}$} & $\begin{array}{l}\text { Conc. } \\
\mathrm{mg} / \mathrm{mL}\end{array}$ & $\begin{array}{l}\text { IZD } \\
\mathrm{mm}\end{array}$ & \multirow{4}{*}{$\begin{array}{c}\mathrm{EtOH} \\
\mathrm{k}\end{array}$} & $\begin{array}{l}\text { Conc. } \\
\mathrm{mg} / \mathrm{mL}\end{array}$ & $\begin{array}{l}\text { IZD } \\
\mathrm{mm}\end{array}$ \\
\hline & 100 & $20 \pm 0.34$ & & 100 & $16 \pm 0.43$ & & 100 & $16 \pm 0.12$ & & 100 & $8 \pm 0.11$ \\
\hline & 10 & $18 \pm 0.23$ & & 10 & $10 \pm 0.42$ & & 10 & $11 \pm 0.34$ & & 10 & $15 \pm 0.23$ \\
\hline & 1 & $12 \pm 0.98$ & & 1 & $2 \pm 0.65$ & & 1 & $12 \pm 0.54$ & & 1 & $12 \pm 0.14$ \\
\hline \multirow{4}{*}{$\begin{array}{l}\mathrm{MeOH} \\
\mathrm{c}\end{array}$} & $\begin{array}{l}\text { Conc. } \\
\mathrm{mg} / \mathrm{mL}\end{array}$ & $\begin{array}{l}\text { IZD } \\
\mathrm{mm}\end{array}$ & \multirow{4}{*}{$\begin{array}{c}\mathrm{MeOH} \\
\mathrm{f}\end{array}$} & $\begin{array}{l}\text { Conc. } \\
\mathrm{mg} / \mathrm{mL}\end{array}$ & $\begin{array}{l}\text { IZD } \\
\mathrm{mm}\end{array}$ & \multirow{4}{*}{$\underset{\mathrm{i}}{\mathrm{MeOH}}$} & $\begin{array}{l}\text { Conc. } \\
\mathrm{mg} / \mathrm{mL}\end{array}$ & $\begin{array}{l}\text { IZD } \\
\text { mm }\end{array}$ & \multirow{4}{*}{$\begin{array}{c}\mathrm{MeOH} \\
1\end{array}$} & $\begin{array}{l}\text { Conc. } \\
\mathrm{mg} / \mathrm{mL}\end{array}$ & $\begin{array}{l}\text { IZD } \\
\mathrm{mm}\end{array}$ \\
\hline & 100 & $19 \pm 0.23$ & & 100 & $17 \pm 0.65$ & & 100 & $16 \pm 0.76$ & & 100 & $12 \pm 0.87$ \\
\hline & 10 & $17 \pm 0.12$ & & 10 & $12 \pm 0.34$ & & 10 & $14 \pm 0.13$ & & 10 & $8 \pm 0.81$ \\
\hline & 1 & $7 \pm 0.54$ & & 1 & - & & 1 & $7 \pm 0.34$ & & 1 & $16 \pm 0.34$ \\
\hline
\end{tabular}

$(12 \pm 0.87)$ and ethanolic $(10 \pm 0.23)$ extracts, while there is no inhibition zone for aqueous extract. Furthermore, our findings disclosed that the extracts were more effective against Escherichia coli and Salmonella enterica as gramnegative bacteria and Staphylococcus aureus as a grampositive bacterium. However, extracts showed a good zone of inhibition against the growth of gram-positive bacterium due to the presence of outer membrane of gramnegative bacteria and the enzymes of the periplasmic spaces which act as a barrier against numerous antibiotic molecules and can break down foreign molecules, respec- tively [22]. According to results, Areca Nut is rich in tannins, terpenoids, alkaloids, and flavonoids [22], and tannin in Areca Nut is effective to inhibit gram-positive bacteria. Tannin binds with peptide on peptidoglycan component from cell walls which in turn disturb the integrity of bacterial cell walls, which cause bacterial cell damage [24, 25]. Finally, it led to disturbance of metabolism process and subsequently the death of cells [26]. It can be deduced that methanolic extracts showed more response to inhibit the growth of all pathogens. The presence of different bioactive chemical agents in the extracts may be due to the 


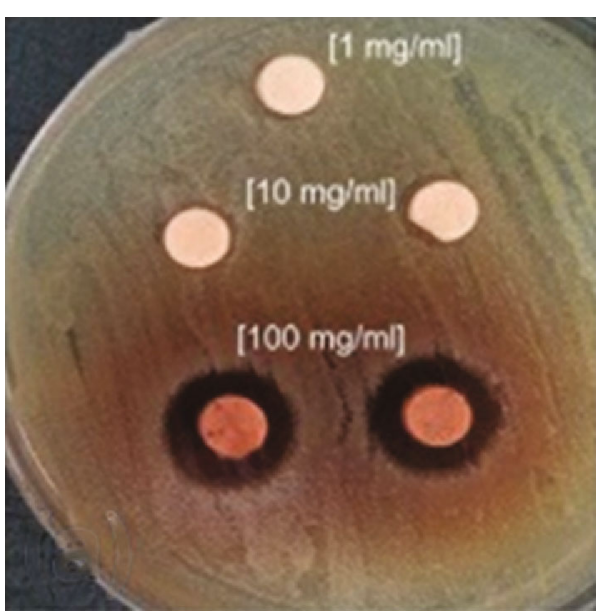

(a)

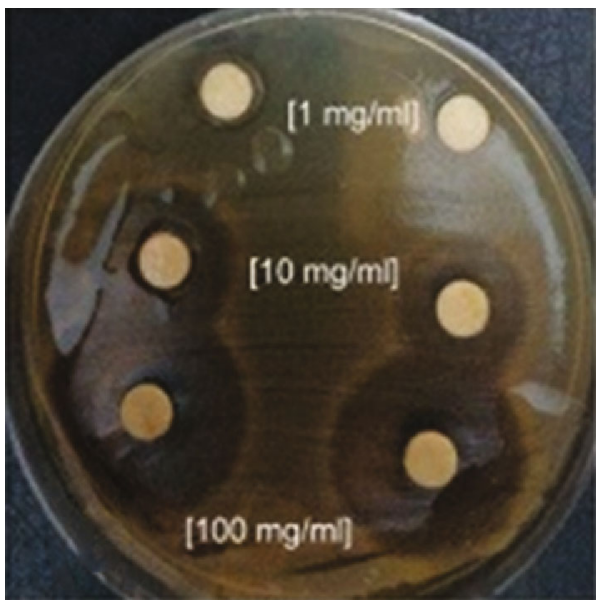

(c)

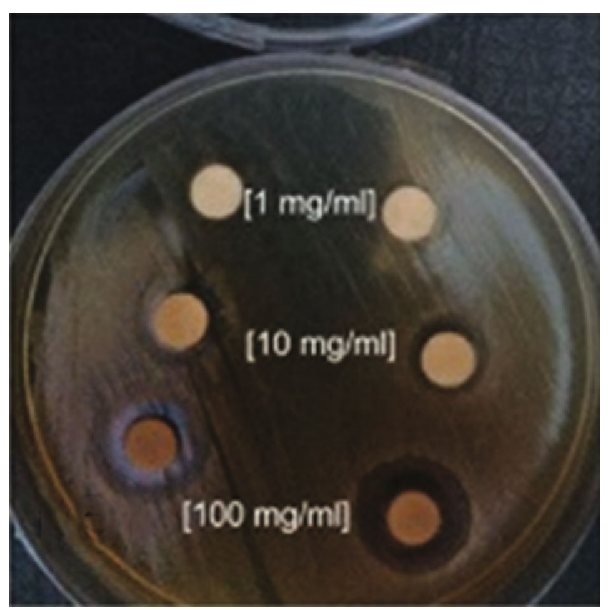

(e)

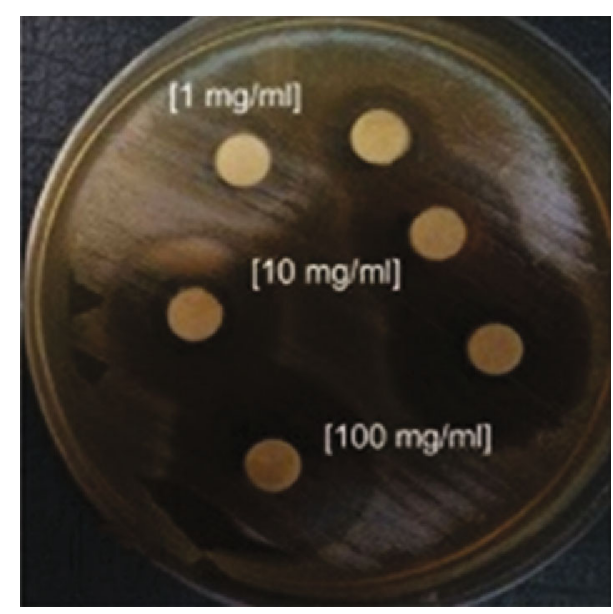

(b)

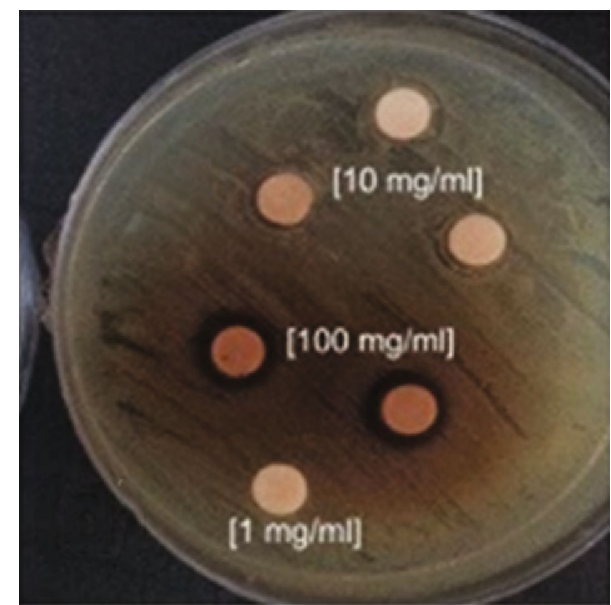

(d)

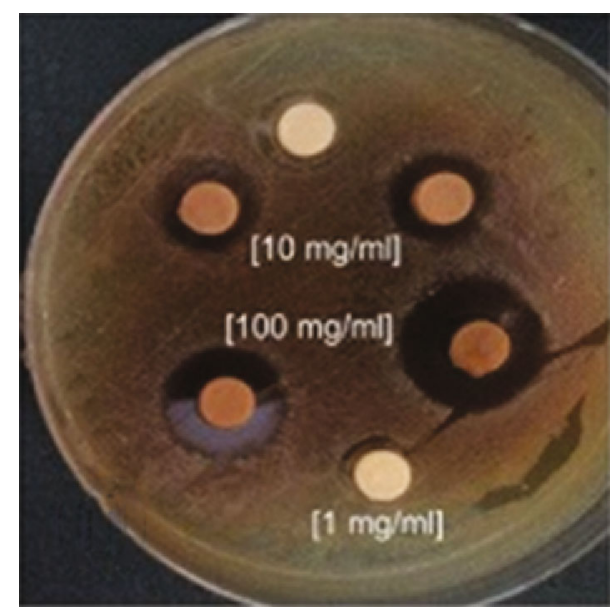

(f)

FIgUre 2: Continued. 


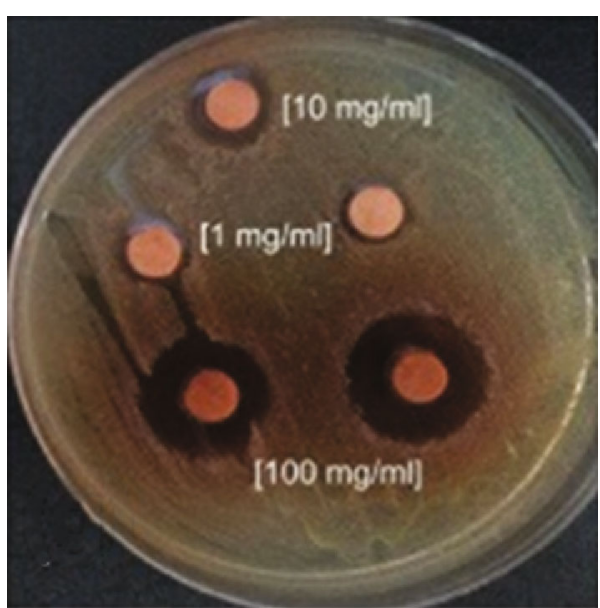

(g)

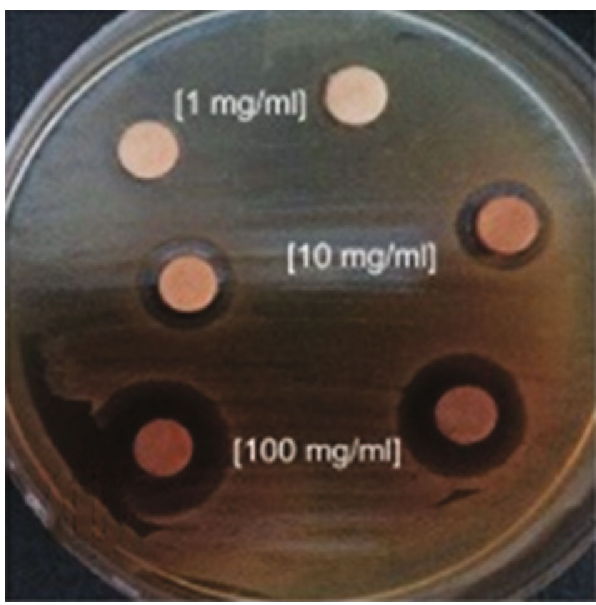

(i)

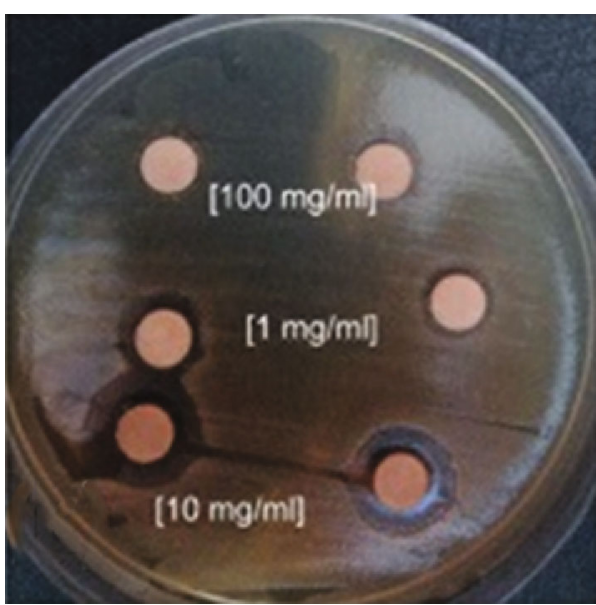

(k)

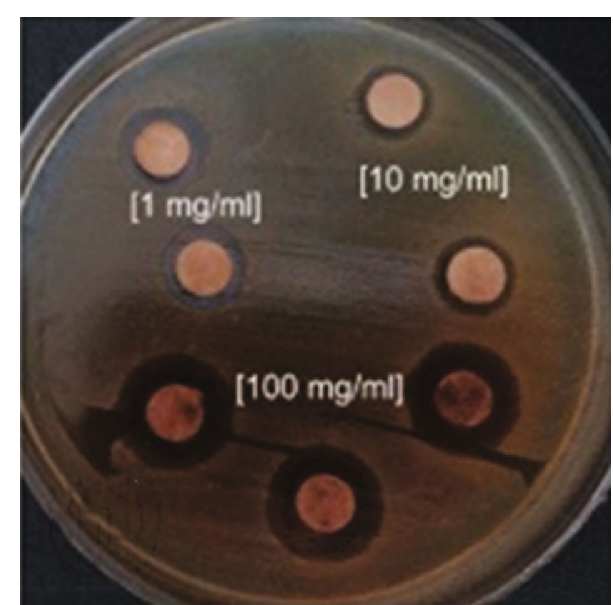

(h)

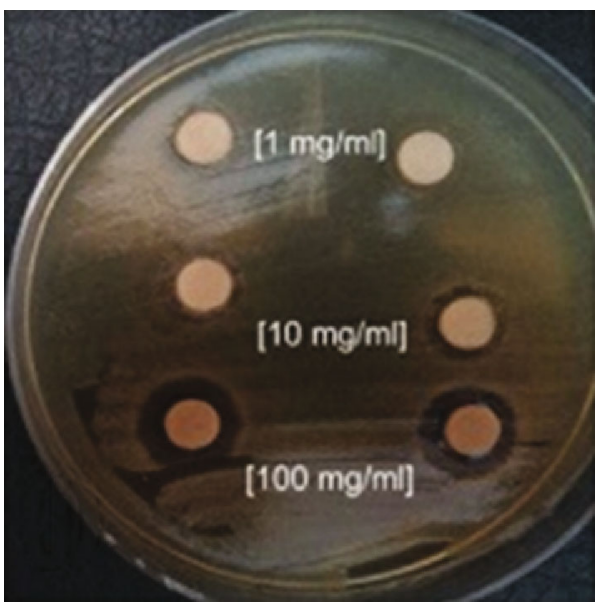

(j)

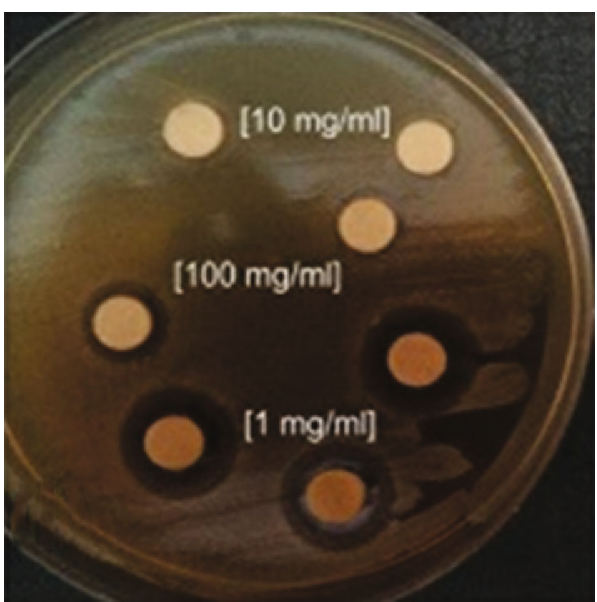

(l)

Figure 2: Inhibitory activity of Areca Nut extracts on Staphylococcus aureus, Escherichia coli, Salmonella, and Enterobacter aerogenes in various solvents by disc diffusion method, Escherichia coli (a) aqueous, (b) ethanolic, and (c) Methanolic; Staphylococcus aureus (d) aqueous, (e) ethanolic, ( $\mathrm{f}$ ) methanolic; Salmonella enterica (g) aqueous, (h) ethanolic, and (i) methanolic; and Enterobacter aerogenes (j) aqueous, (k) ethanolic, and (l) methanolic.

antibacterial properties of plants. In this study, extracts showed a better antibacterial activity in results of containing tannins. Maybe tannins have the ability to inactivate several enzymes, microbial adhesion, and cell envelope transport proteins [27]. The statistical results of disc diffusion analysis presented the significance for all pathogens (Table 3). The extracts showed a good zone of inhibition $(p<0.05)$ against all of pathogens. 
3.3. Results of MIC and MBC. To evaluate the effectiveness of the extracts to inhibit the growth of Staphylococcus aureus, Escherichia coli, Salmonella enterica, and Enterobacter aerogenes, MIC assay was employed. Low-MIC and high-MIC values indicate high and low activity of extracts against pathogens, respectively [27]. As a result, the methanolic extract had a considerable antibacterial activity with MIC value of $1.56 \mathrm{mg} / \mathrm{mL}$ against Escherichia coli. According to, the MIC value of the extracts agreed with their corresponding antibacterial activities. The results of MIC revealed that methanolic and ethanolic extracts have antibacterial activities against all pathogens, while aqueous extracts have a lower antibacterial effect due to the existence of nonpolar molecules in the extracts. As known, the polar components cannot dissolve nonpolar components and hence, antibacterial activities of aqueous extract are decreased. Since methanol has a high potential to dissolve all polar and nonpolar molecules, the methanolic extract showed higher inhibition against the pathogens, especially Escherichia coli $(1.56 \mathrm{mg} / \mathrm{mL})$. Also, methanolic Areca Nut fruit extract displayed the lowest MBC against Staphylococcus aureus and Enterobacter aerogenes ) $3.12 \mathrm{mg} / \mathrm{mL}$ (. In this survey, the methanolic extract showed more acceptable effects against the bacterial strains compared with aqueous extract. It can be attributed to the presence of antibacterial agents with different polarities in Areca Nut extract or in other word difference in the solvent efficiency to isolate biologically active compounds. Moure et al. reported that antioxidant and antibacterial properties also depend upon the extraction location and applied techniques [28]. The type of solvent is also one of the most important factors in the isolation of antibacterial and antioxidant substances, as these agents have different polarities [29]. Contrary to our findings, Rahman et al.'s study indicated that methanolic Areca Nut fruit extract substantially inhibited Staphylococcus aureus growth at $20 \mathrm{mg} / \mathrm{mL}$ concentration, while displayed no growth inhibitory effect on Escherichia coli. [30]. Moreover, Ghanwate et al. reported that using disk diffusion approach, aqueous extract of Areca Nut fruit at the concentration of $100 \mathrm{mg} / \mathrm{mL}$ inhibited bacterial growth of Escherichia coli, Salmonella enterica, and Staphylococcus aureus with similar efficiency (similar inhibition zone sizes) [31].

\subsection{Antibacterial Activity of Areca Nut Fruit Extracts in Cake.} The antibacterial activity of different concentrations of methanolic, ethanolic, and aqueous extracts of Areca Nut fruit against selected pathogens in cake was studied, and results are presented in Table 4 and Figure 2. Based on the inhibition zone diameter (IZD), the ethanolic extract of Areca Nut fruit was effective in growth control of the Escherichia coli $(20 \pm 0.34 \mathrm{~mm}, \quad 100 \mathrm{mg} / \mathrm{mL})$, Staphylococcus aureus $(16 \pm 0.43 \mathrm{~mm}, \quad 100 \mathrm{mg} / \mathrm{mL}), \quad$ Salmonella enterica $(16 \pm 0.12 \mathrm{~mm}, 100 \mathrm{mg} / \mathrm{mL})$, and Enterobacter aerogenes $(15 \pm 0.23 \mathrm{~mm}, 10 \mathrm{mg} / \mathrm{mL})$. The methanolic extract of Areca Nut fruit had a maximum level of inhibition zone against Escherichia coli $(19 \pm 0.23 \mathrm{~mm}, 100 \mathrm{mg} / \mathrm{mL})$, Staphylococcus aureus $(17 \pm 0.65 \mathrm{~mm}, 100 \mathrm{mg} / \mathrm{mL})$, Salmonella enterica $(16 \pm 0.76 \mathrm{~mm}, 100 \mathrm{mg} / \mathrm{mL})$, and Enterobacter aerogenes $(16 \pm 0.34 \mathrm{~mm}, 1 \mathrm{mg} / \mathrm{mL})$. Aqueous extract of Areca Nut fruit had a maximum level of inhibition zone against Escherichia coli $(15 \pm 0.23 \mathrm{~mm}, 100 \mathrm{mg} / \mathrm{mL})$, Staphylococcus aureus $(10 \pm 0.45 \mathrm{~mm}, \quad 100 \mathrm{mg} / \mathrm{mL}), \quad$ Salmonella enterica $(15 \pm 0.65 \mathrm{~mm}, 100 \mathrm{mg} / \mathrm{mL})$, and Enterobacter aerogenes $(12 \pm 0.65 \mathrm{~mm}, 100 \mathrm{mg} / \mathrm{mL})$. As a result, methanolic extract of Areca Nut fruit was the most effective antibacterial agent against all pathogens at $100 \mathrm{mg} / \mathrm{mL}$ concentration. However, aqueous extract of Areca Nut fruit was the least effective antimicrobial agent, and it did not produce antibacterial activity against Staphylococcus aureus and Escherichia coli bacteria at low concentration. Pour plate counts of four main pathogens in cakes including Areca Nut extracts at $1^{\text {st }}, 30^{\text {th }}, 60^{\text {th }}$, and $80^{\text {th }}$ days of baking did not show any observable colonies, whereas the control samples showed the count of $1.12 \times 10^{3}$ cfu/g for each pathogen.

\section{Conclusion}

Methanolic fruit extract of Areca Nut showed an antibacterial effect on both gram-positive and gram-negative bacteria. In addition, results disclosed that the extracts were more effective against Escherichia coli as a gram-negative bacterium when compared with other pathogens. For Escherichia coli, a minimum inhibitory concentration (MIC) of $1.56 \mathrm{mg} / \mathrm{mL}$ was established. Also, the antibacterial activity of Areca Nut fruit extracts in a baked cake revealed that methanolic extract has the most effective antibacterial agent against all pathogens at $100 \mathrm{mg} / \mathrm{mL}$ concentration. Additionally, the cakes containing Areca Nut fruit extract displayed acceptable and promising results in terms of technological, organoleptic, and rheological characteristics of the specimens, so that the cakes were approved regarding sensory attributes, notably texture, flavor, and smell. Therefore, our study highlights the potential use of these extracts as natural additives in cake industry to satisfy consumers' needs to use natural preservatives in foods and enhance food safety. Further evaluation of Areca Nut fruit on antiracial activity of other main pathogens in food and bakery industries will be highly effective in the formulation of policies for the management of food safety.

\section{Data Availability}

Data is available on request.

\section{Conflicts of Interest}

All the authors declare that there are no conflicts of interest.

\section{References}

[1] L. Totelin, "When foods become remedies in ancient Greece: the curious case of garlic and other substances," Journal of Ethnopharmacology, vol. 167, pp. 30-37, 2015.

[2] A. A. Basti, A. Misaghi, M. H. Moosavy, T. Zahraei Salehi, and G. Karim, "Effect of Zataria multiflora Boiss. essential oil on the growth of Staphylococcus aureus in a commercial barley soup," Journal of Medicinal Plants Research, vol. 2, no. 22, pp. 91-98, 2007.

[3] M. Khoddami, M. Sheikh Hosseini, and M. Hassanshahian, "Antibacterial activity of Semenovia suffruticosa (Essential 
Oil) against pathogenic bacteria and determination of chemical composition of essential oils by gas chromatography-mass spectrometry analysis in four regions of Kerman," Journal of Dietary Supplements, vol. 16, no. 5, pp. 530-540, 2019.

[4] Z. Mohsenipour and M. Hassanshahian, "The inhibitory effect of Thymus vulgaris extracts on the planktonic form and biofilm structures of six human pathogenic bacteria," Avicenna Journal of Phytomedicine, vol. 5, no. 4, pp. 309-318, 2015.

[5] R. J. Sullivan, J. S. Allen, C. Otto, J. Tiobech, and K. Nero, "Effects of chewing betel nut (Areca catechu) on the symptoms of people with schizophrenia in Palau, Micronesia," Journal of Agricultural and Food Chemistry, vol. 177, no. 2, pp. 174-178, 2000.

[6] A. Srimany, C. George, H. R. Naik, D. G. Pinto, N. Chandrakumar, and T. Pradeep, "Developmental patterning and segregation of alkaloids in areca nut (seed of Areca catechu) revealed by magnetic resonance and mass spectrometry imaging," Phytochemistry, vol. 125, pp. 35-42, 2016.

[7] W. M. Zhang, W. Y. Huang, W. X. Chen, L. Han, and H. D. Zhang, "Optimization of extraction conditions of areca seed polyphenols and evaluation of their antioxidant activities," Molecules, vol. 19, no. 10, pp. 16416-16427, 2014.

[8] M. Rashid, S. Shamsi, R. Zaman, and A. Ilahi, "Areca catechu: enfolding of historical and therapeutical traditional knowledge with modern update," International Journal of Pharmacognosy, vol. 2, pp. 221-228, 2015.

[9] E. Verawati, R. Pambayun, T. Widowati, B. Santoso, and S. Puspa Dewi, "Antibacterial activity toward Streptococcus mutans and antioxidant from traditional betel chew formulation of Indonesia," Journal of Microbial \& Biochemical Technology, vol. 9, no. 6, pp. 316-320, 2017.

[10] W. Peng, Y. J. Liu, N. Wu et al., “Areca catechu L. (Arecaceae): A review of its traditional uses, botany, phytochemistry, pharmacology and toxicology," Journal of Ethnopharmacology, vol. 164, pp. 340-356, 2015.

[11] M. Joshi, K. Gaonkar, S. Mangoankar, and S. Satarkar, "Pharmacological investigation of Areca catechu extracts for evaluation of learning, memory and behavior in rats," International Journal of Current Pharmaceutical Research, vol. 1, no. 6, pp. 128-132, 2012.

[12] D. Wang, L. Zhou, W. Li, H. Zhou, and G. Hou, "Anticoccidial effects of areca nut (Areca catechu L.) extract on broiler chicks experimentally infected with_Eimeria tenella_," Experimental Parasitology, vol. 184, pp. 16-21, 2018.

[13] S. D. Agustina, Y. Rizal, A. Ardi, and M. E. Mahata, "Extraction of catechins from Areca catechu L. peel with different solvent type for feed additive of broiler," The International Journal of Environmental Research, vol. 5, no. 6, pp. 17961802, 2019.

[14] P. Jaiswal, P. Kumar, V. K. Singh, and D. K. Singh, “Areca catechu L., a valuable herbal medicine against different health problems," Research Journal of Medicinal Plant, vol. 5, pp. 145-152, 2011.

[15] P. Boniface, S. K. Verma, H. S. Cheema, M. P. Darokar, and A. Pal, "Evaluation of antimalarial and antimicrobial activites of extract and fractions from Areca catechu," International Journal of Infectious Diseases, vol. 21, pp. 228-229, 2014.

[16] H. S. Shekhar Sharma, C. C. Gilmore, and H. B. Sharma, "Comparison of chemical components of healthy and spoiled areca nut," Mycological Research, vol. 95, no. 6, pp. 747-751, 1991.
[17] N. S. Surendiran and T. V. Yuvaraj, "Antibacterial, antioxidant, in vitro \& in vivo immuno-modulatory studies of Areca catechu in mice," Iranian Journal of Pharmaceutical Research, vol. 3, no. 11, pp. 2678-2681, 2010.

[18] B. Santoso, E. Verawati, T. Wardani Widowati, S. Rusdiana Puspa Dewi, and R. Pambayun, "Functional characteristics of marshmallow with Kinang (chew of betel) extract addition," Journal of Food and Nutrition Research, vol. 7, no. 1, pp. 1-5, 2019.

[19] W. Zhang, B. Li, L. Han, and H. Zhang, "Antioxidant activities extract of Areca seed, husk and flower," African Journal of. Biotechnology, vol. 16, pp. 3887-3892, 2009.

[20] S. M. Smith, C. O'Morain, and D. McNamara, "Antimicrobial susceptibility testing for Helicobacter pylori in times of increasing antibiotic resistance," World Journal of Gastroenterology, vol. 20, no. 29, pp. 9912-9921, 2014.

[21] R. G. Board and H. S. Tranter, Egg Science and Technology, W. J. Stadelman and O. J. Cotterill, Eds., Haworth Press, Inc., New York, 1995.

[22] M. S. Khan and M. S. Akhter, "Antibacterial and cytotoxic activities of Areca catechu L.(betel nut)," To Chemistry Journal, vol. 5, pp. 55-68, 2020.

[23] Z. Mohsenipour and M. Hassanshahian, "Antibacterial activity of Euphorbia hebecarpa alcoholic extracts against six human pathogenic bacteria in planktonic and biofilm forms," Jundishapur Journal of Microbiology, vol. 9, no. 6, pp. e34701-e34708, 2016.

[24] R. Pambayun, M. Gardjito, S. Sudarmadji, and K. Rahayu, "Phenolic conent and antibacterial characteristics from several types of gambier product extract (Uncaria gambir Roxb)," Indonesian Journal of Pharmacy, vol. 18, no. 3, pp. 141-146, 2017.

[25] H. Akiyama, K. Fujii, O. Yamasaki, T. Oono, and K. Iwatsuki, "Antibacterial action of several tannins against Staphylococcus aureus," Journal of Antimicrobial Chemotherapy, vol. 48, no. 4, pp. 487-491, 2001.

[26] P. W. Taylor, J. M. Hamilton-Miller, and P. D. Stapleton, "Antimicrobial properties of green tea catechins," Food Science and Technology Bulletin, vol. 2, no. 7, pp. 71-81, 2005.

[27] B. Mummed, A. Abraha, T. Feyera, A. Nigusse, and S. Assefa, "In Vitro antibacterial activity of selected medicinal plants in the traditional treatment of skin and wound infections in Eastern Ethiopia," BioMed Research International, vol. 2018, Article ID 1862401, 8 pages, 2018.

[28] A. Moure, J. M. Cruz, D. Franco et al., "Natural antioxidants from residual sources," Food Chemistry, vol. 72, no. 2, pp. 145-171, 2001.

[29] M. Z. Zolfaghari, R. Gaeini, N. Kalhor, M. Khalilian et al., "Determination of microbial contamination of the milk and asteurized dairy products produce in the Qom province," Journal of Microbial World, vol. 5, pp. 47-57, 2012.

[30] M. A. Rahman, P. Sultana, M. S. Islam, M. T. Mahmud, M. M. O. Rashid, and F. Hossen, "Comparative antimicrobial activity of Areca catechu nut extracts using different extracting solvents," Bangladesh Journal of Microbiology, vol. 56, pp. 1923, 2014.

[31] N. A. Ghanwate, P. V. Thakare, P. R. Bhise, A. Dhanke, and S. Apotikar, "Prevention of biofilm formation in urinary catheter by coating enzymes/gentamycin/EDTA," International Journal of Biotechnology and Bioengineering, vol. 6, pp. 899901, 2012 . 